FACTA UNIVERSITATIS

Series: Linguistics and Literature Vol. 16, N² 2, 2018, pp. 107-120

https://doi.org/10.22190/FULL1802107E

Original Scientific Paper

\title{
SERBIAN TRANSLATION OF BILL BRYSON'S MADE IN AMERICA: SOURCE TEXT EQUIVALENCE AS THE DEFINING CRITERIA OF TRANSLATION
}

\author{
UDC 81'255
}

\author{
811.111'255:811.163.41
}

Borislava Eraković

University of Novi Sad, Faculty of Philosophy, Novi Sad, Serbia

\begin{abstract}
The purpose of this paper is to illustrate the effect of an implicit, equivalencebased concept of translation on the translator's decision-making by examining the Serbian translation of the non-literary work Made in America by the famous American travel writer Bill Bryson. The translation does not contain any binary errors that would suggest an incompetent translator, but it shows problems with intratextual coherence for the target reader. The reasons for this can be linked to an underlying concept of translation which is based solely on the search for equivalence to the source text, disregarding the purpose of the translation and the viewpoint of the target reader. The paper contrasts the effect of this approach to the effects of a functionalist approach to translation and discusses its implications for a more visible role for the translator.
\end{abstract}

Key words: functionalist approach, equivalence, intratextual coherence, intertextual coherence, translator's role

\section{INTRODUCTION}

One of the conclusions of the famous dialogue on the subject by Chesterman and Wagner (2002), covering a range of issues where theory and practice can meet, was that theory should analyse translation practice (Chesterman and Wagner 2002:133, 136). Analysis of the works of established translators can lead to insight into ways of solving translation problems as well as disclose issues that need to be further addressed. This paper represents such an endeavour. The example we use is Bill Bryson's Made in America, a non-literary book in which he describes the development of General American

Submitted June 6, 2018, accepted for publication August 26, 2018

Corresponding author: Borislava Eraković

University of Novi Sad, Faculty of Philosophy

E-mail : borislava.erakovic@ff.uns.ac.rs 
English (GAE) language and culture through history and its Serbian translation. Through analysing the translation, by an established translator (and a successful Serbian SF writer), our aim is to identify the underlying notion of translation that guides the translator's choices.

The theory we discuss in this paper is the understanding of translation in its traditional sense, as a search for equivalence to the source text (ST) as its only criterion, which still seems to be the default approach to translation in Serbia, regardless of the genre. ${ }^{1}$ In translation theory, this is often termed as the equivalence paradigm, and we will present it shortly. We will also contrast it with the alternative, functionalist approach to translation and compare the outcomes of both approaches in the text we analyse.

It is important to note that our focus here is not on identifying what Pym calls 'binary translation errors' (Pym 1992:4-5), i.e. elementary errors which are clearly wrong and most often caused by inadequate linguistic competence. There are two reasons for this: firstly, they are not present in this translation, and secondly, there is not much to learn about translation from the analysis of errors based on inadequate language competence. An analysis of translation errors can have direct didactic purpose in a translation classroom, but it does not have significant explanatory potential when it comes to understanding how translations function within cultures (cf. Snell-Hornby 2006: 44; Holmes 2000:100; Pym 1992:5). Furthermore, binary errors in translation are avoidable when standard procedures for quality translation are applied - the text is translated by a competent translator and reviewed by at least one other competent translator. Translations with elementary linguistic errors would therefore belong to the realm of publishing policy, which can also be a legitimate object of analysis in translation studies, but is outside the scope of this paper. Our aim is to show how an underlying notion of translation can guide a translator's choices toward procedures which lead to a translation that has no 'errors' but is near incomprehensible for the target reader.

In the following section, we present the most common criticisms of equivalence to the ST as the sole criterion in translation and the main principles of a functionalist perspective in translation. We then proceed to discuss examples of several focal translation problems in Bill Bryson's book by contrasting the effects of the translator's choices to the effects of applying the alternative paradigm.

\subsection{Equivalence to the $S T$ as the only criterion in translation}

The notion of equivalence, as one of the key concepts in translation theory, was crucial in establishing the study of translation as a scientific endeavour during the 1950s and 1960s by many accounts (cf. Fawcett 1997:53; Snell-Hornby 1988:14; Pym 1995:157-9; Nord 2005:26). It grew from structural linguistics and while at first it focused on distinct lower-level units (phonological, graphological, grammatical, lexical), in time, equivalence grew to encompass the textual level and the level of discourse. Nida and Taber's (1969:12) famous definition of equivalence states that "translating consists in reproducing in the receptor language the closest natural equivalent of the source language message, first in terms of meaning and secondly in terms of style."With the aim of

\footnotetext{
${ }^{1}$ I base this conclusion on my published analyses of how prominent Serbian literary translators deal with substandard language in translation (2002), childish talk in books for children $(2010,2013)$ and context in news translation (2018), as well as on numerous source and target texts compared during the two decades of my work as a translation teacher.
} 
identifying equivalence relations in translation from one language into another, numerous types of equivalence have been identified and defined, focusing on form (Catford's (1965:27) and Nida's (1964:159) formal correspondence), unit level (Koller's denotative, connotative, text-normative, pragmatic, formal), naturalness and function (Nida's dynamic equivalence). ${ }^{2}$ Such conceptualisations of ST-TT relations have found applications in machine translation and translator training (Pym 1992:159, Baker 2011:5; Kenny 2009:96). The notion has, however, also been significantly devalued in translation studies since the 1980s (Snell-Hornby 1988:16; Munday 2008:46; Colina 2011:45; Leal 2012:43-4), particularly the idea that "translators could somehow convey the 'same', necessarily stable and language-independent meaning as their ST" (Kenny 2009:96). Snell-Hornby (1988:21) quotes Newmark's ${ }^{3}$ statement about equivalence being another "dead duck - either too theoretical or too arbitrary". The main objection has been the impossibility of defining equivalence in a way that would adequately reflect the real-life translation activity and on which translation scholars could agree.

This is particularly noticeable in the translation of cultural realia. The problem of transferring elements of culture from one language into another is difficult to resolve in a framework where the ST is always the main criterion. Nord (2006:26) notes that the problem is also that target texts (TT) which do not comply with the standard of equivalence because they are "too faithful" (word-for-word) or "too free" (adaptation, free rendering, paraphrase) are not accepted as translations. Cultural elements are famous untranslatables which require the translator's intervention regarding the amount of information presented to the target reader. Translator's notes, descriptive translation, addition of relevant information either in the text itself or in the form of the translator's note are often inevitable - provided that these strategies are allowed. The ST focused, equivalence-based notion of translation will typically keep such interventions to a minimum, because they damage the illusion of an 'equivalent effect'. Furthermore, translator's notes are often taken as signs of translator incompetence, admittance of defeat, and proof that the ST, the original, is essentially "untranslatable". Hence the publishers, editors and translators themselves tend to resort to them sparingly.

It is therefore not surprising that toward the end of the $1980 \mathrm{~s}$, some translation scholars started voicing the need to extend comparisons between the ST and TT "beyond the confines of differential semantics and grammar into the broader areas of text structure and functioning, into the sociocultural functioning of translation and how it is shaped and constrained by the place and time in which it takes place" (Fawcett 1997:145). Pym considers himself as belonging to a small group of translation scholars (alongside Gutt, Neubert and Stecconi) who believes equivalence should survive as one of the core concepts in translation studies. Still, he importantly redefines it as something a translator produces, and not something s/he seeks, "rather than force any translator to become an 'equivalence seeker' [...] and assume any 'rational recovery of original meaning' [...], the translator is an equivalence producer, a professional communicator working for people who pay to believe that, on whatever level is pertinent, A is equivalent to B" (Pym 1995:167). This change in the understanding of what it means to translate is reflected in

\footnotetext{
${ }^{2}$ For a description of equivalence types, see for example Kenny 2009:97 and Leal 2012:41-42.

${ }^{3}$ Newmark was a staunch believer in adherence to the source text: "You abandon the SL text - literal translation if you like (which, for the purpose of this argument, I couple with mandatory or virtually mandatory shifts and word-order changes) only when its use makes the translation referentially and pragmatically inaccurate, when it is unnatural, when it will not work" (Newmark 1988:31).
} 
functionalist approaches to translation, whose origins are generally related to skopos theory, conceptualised by Hans Vermeer and a circle of scholars working at the University of Germersheim in the 1980s.

\subsection{The functionalist perspective on translation}

The functionalist approach to translation is primarily focused on the target side of the translation process - it is said to have "de-throned" the ST (Snell-Hornby 2006:54). This is a holistic view of translation which involves careful analysis of both the ST and TT in relation to the purpose or function of translation, which is defined not by the features of the ST, but by the needs of the target culture. The relevant factors here include the sender or the initiator of the translation process as well as the source-text author and the translator, and both groups of readers. The starting question in the process is why something needs to be translated - and all other decisions are made from there (Nord 2013:202). Other core concepts are intratextural coherence, intertextual coherence and the principle of loyalty.

Intratextual coherence as a goal of translation posits that the translation should make sense for the target reader or "become part of a world continuum which can be interpreted by the receiver as "coherent with his situation"” (Nord 2005:27).

Intertextual coherence, i.e. fidelity to the features of the ST as a goal of translation, depends on the purpose of translation. If the TT is deemed to have the same function as the ST, then a careful analysis of the ST's features will aim to establish functional equivalents at the level required. But this is only one possible purpose of translation, and even when the overall function of the two texts is the same, the function of particular segments may not be. Translation procedures such as addition, omission and paraphrase, frowned upon in the equivalence framework, are legitimate in the functionalist framework, because the "adjustment or 'adaptation' of the ST to target-culture standards is a procedure that is part of the daily routine of every professional translator" (Nord 2005:28).

Finally, the principle of loyalty is understood as a moral category, according to which the translator is "responsible to both the source-text sender and the target text receiver" (Nord 2005:32; 2013:205). It replaces the notion of fidelity to the ST. Nord notes that while fidelity is a relationship between texts, loyalty is a relationship between people: the translator should not betray the expectations of the end users, and should respect the intentions of the ST author.

This approach puts the reins of the translation process into the hands of the translator as a qualified competent professional. The translator's bicultural and bilingual competence uniquely enables him/her to make decisions regarding the translation purpose and to select the most appropriate procedures to solve any translation problems which arise (Nord 2013:204). This is in sharp contrast to an approach based on equivalence to the ST as the paramount principle, because, as we shall see shortly, and as Nord has noted, the ST cannot be the only legitimate foundation for the determination of equivalence, since 'a ST analysis is unable to meet' such a demand (Nord 2005:26). In the following analysis we will illustrate the practical implications of these theoretical stances, after a few words about the challenges of Bill Bryson's book. 


\section{CHALlENGING ASPECTS OF MADE IN AMERICA}

Bill Bryson's humorous and informative survey of the development of GAE language and culture presents how historical events and characters have helped shape GAE throughout the centuries. Made in America abounds in words and expressions from various fields: technology, food, domestic life, marketing, movies, sports, politics, space exploration and many others. Bryson describes the phonological, orthographical and semantic peculiarities of GAE, and offers a series of examples on every page, sometimes going for half a page or more. The book contains words and phrases denoting objects (saw-buck), weather conditions (snowstorm, tornado, blizzard), types of food (Johnnycake, jerked beef), historical or imaginary characters (living the life of Riley), locations, plants, insects (mosquito), and animals, to name just a few. They reflect Bryson's understanding of how history created conditions which gave rise to the linguistic peculiarities of GAE.

A large portion of the book is also about how GAE came to differ from British English (BE). The examples Bryson uses are immediately clear to the educated ST reader: for most of the words and expressions listed, s/he would know how they are written in at least one of the variants and what has changed in their spelling; how they used to be pronounced and what has changed; the denotative meaning of the individual words comprising an idiom - and their combined meaning. When given longish word lists, the ST reader knows the place they occupy in GAE - how common they are, the register they belong to and the context of their use. This helps the source reader to understand why and how GAE has changed and how it has changed in relation to BE.

As a result of the difficulty in understanding the topic without understanding the language, this book is an unusual choice for translation. It makes extremely interesting reading for a lover of languages and American history and culture, but is probably less accessible and relevant for a non-English speaking reader, perhaps familiar with Bryson's light, world-famous travelogues ${ }^{4}$, who may reach for this book expecting more of the same. Non-speakers of English do not possess the presupposed knowledge needed to follow Bryson's description of linguistic changes. If a sentence says something about a group of English words, the reader needs to know their meaning and how they are normally spelled and pronounced today. Translating the words into Serbian hides all this, and the target text readers cannot meaningfully follow the aspect of change Bryson is describing. The translator of this book can therefore never forget to take this into account. In this book about the English language one of the questions is bound to be what to translate, what to add, and whether to leave something out, in order to make the work meaningful to the target reader. The translator cannot escape visibility in this book (should s/he want to). The path the translator chooses indicates the underlying notion of translation $\mathrm{s} / \mathrm{he}$ aspires to. So, while a book on language and culture is anything but an easy translation task, regardless of the skill level of the translator, it is one where the role of translation theory is easy to show, which is the reason why we have chosen it for our analysis.

\subsection{Whose English is this?}

One of the questions in the translation of Bryson's description of AE is how to harmonize the narrator's perspective, which is realized through the use of personal

\footnotetext{
${ }^{4}$ Some of Bryson's most famous travelogues include Neither Here nor There (1991), Notes from a Small Island (1995) and The Road to Little Dribbling: More Notes from a Small Island (2015).
} 
pronouns, the examples he cites and the language of the translation. We see this in the following excerpt, in which the author identifies himself as a member of the American culture (we no longer use, we would not refer.., not enough to confuse us) as he describes archaic forms of AE spelling:

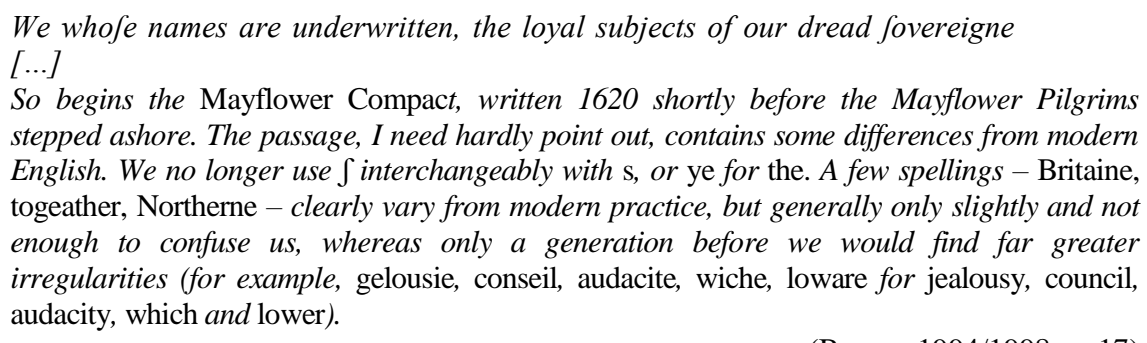

(Bryson 1994/1998, p. 17)

In the published translation, the main preoccupation in this segment seems to have been preservation of the archaic stylistic markers. The symbol $\int$ is treated as meaningful and is reproduced in Serbian as a stylization of a spelling archaism. Other techniques include close translation of the sentence structure, literal translation of personal references (we, us) and compensation. This last choice creates the greatest obstacle for the achievement of intratextual coherence in Serbian: English archaic spelling of the word togeather is compensated in the translation with a stylistic equivalent - a Church Slavonic word meaning fatherland (otečestvo). The archaic Britaine is transcribed as Britajne, but Northerne is translated with a stylized archaism with the same meaning (severnijem):

Mi, dolepotpifani, odani podanici našeg Jtrašnog fuverena, Gofpodara Kralja Džejmfa, [...]

Ovaj pasus se, ne moram to ni da naglašavam, donekle razlikuje od savremenog engleskog. Više ne koristimo $\int$ umesto s; nekoliko reči - Britajne, severnijem, otečestva očigledno odstupa od savremene prakse, ali uopšte uzevši vrlo malo i nedovoljno da nas zbuni, dok se samo jednu generaciju pre toga moglo naći mnogo većih nepravilnosti [ $\phi]$ Danas ne bismo pominjali "strašnog suverena”,... (Brajson 2010, p. 37)

This paragraph, I need not stress it, is somewhat different from contemporary English. We no longer use $\int$ instead of s; a few words - Britajne, severnijem, otečestva - obviously differ from current practice, but generally speaking, very little or not enough to confuse us, whereas only a generation before one could have found much greater irregularities. (Back translation/BT).

Reference to English and the use of the first person plural in combination with Serbian archaisms severnijem, otečestvo create an incoherent chain (in contemporary English - we no longer use $\int$ - in words like severnijem, otečestva) because severnijem and otečestvo are not English words and the $\int$ symbol as a stylization of archaic spelling is not convincing in Serbian.

All these choices aimed at mimicking the selected features of the ST are not "incorrect"; at the micro-levels they are aimed to reproduce, but taken all together, they make the Serbian text illogical. 
This problem with textual coherence seems not to have escaped the translator completely, because the next decision seems an attempt to limit the damage. The string of words given in brackets (gelousie, conseil, audacite, wiche, loware for jealousy, council, audacity, which and lower) which exemplify archaic English spelling has been omitted from the translation. The translation strategy employed in this segment reveals a preoccupation with the level of grapheme and word, as this is the scope of the effect of the procedures applied, without accommodating them to the reader's ability to recognize the elements compared. As a result, textual coherence in Serbian is not achieved and the main reason for this could be the translator's inability to choose his primary allegiance, which drifts between the ST wording and the TT logic. What is also lacking is a unified framework which would guide the micro level decisions; in a functionalist perspective, this guide is the purpose of the translation and an active consideration of the target reader.

Considering the purpose, the reader, and the principle of loyalty, a coherent set of decisions in this segment could consist of the systematic use of English examples, translated into Serbian inside parentheses (for single words and expressions) or in footnotes. The author's references to himself would also be omitted and replaced with references to English, in the manner illustrated in the following back translation of an alternative Serbian translation:

The letter $\int$ is no longer used interchangeably with $\mathrm{s}$, or ye for the. A few spellings - Britaine, togeather, Northerne - clearly vary from modern practice, but generally only slightly and not enough to be confusing, whereas only a generation before there were far greater irregularities (for example, gelousie, conseil, audacite, wiche, loware for jealousy, council, audacity, which and lower (ljubomora, savet, hrabrost, koji, niži)).

\subsection{Which language is this?}

The next example also shows how adherence to word-level equivalences can result in solutions like the following, where Serbian words are titled 'English' in the translation:

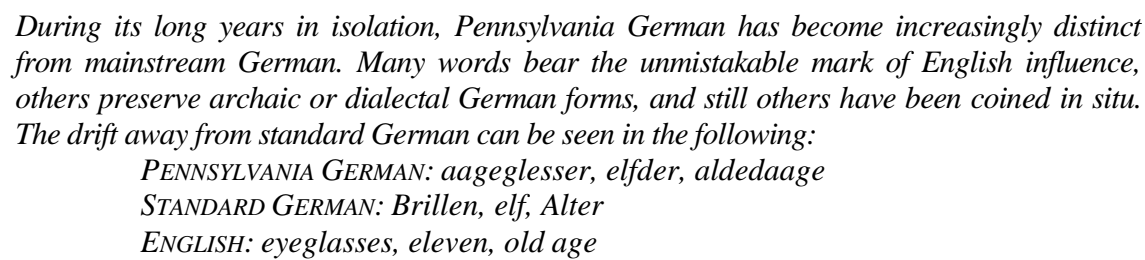

(Bryson 1994/1998, p. 175)

PENSILVANIJSKI NEMAČKI: aageglesser, elfder, aldedaage STANDARDNI NEMAČKI: Brillen, elf, Alter ENGLESKI: naočari, jedanaest, starost

(Brajson 2010, p. 218).

In the translation, while the German title announces German words, the English title announces Serbian words. Even more problematic is that the target reader cannot understand the main point that the wordlists illustrate - how English influenced Pennsylvanian German to such an extent that, for example, Brillen became aageglesser under the influence of eyeglasses. 
In order to cater to the perspective of the target reader, the translation would need to maintain the column with the words in English, alongside information on what the individual words mean.

\title{
2.3. What is the idiom about?
}

Idioms are problematic in every translation. As a firm proponent of the equivalence based approach, Peter Newmark (1988: 81) stated that "the more standard are the collocations, colloquialisms, idioms and stock metaphors, the less likely is a literal translation", meaning that when translating an idiom, which is as a standard expression, the translator should strive to transfer its meaning, not the words which express it. Mona Baker (2011:76-85) envisages several procedures for the translation of idioms, stressing that the choice will depend on the context in which a given idiom is translated. In her opinion, a translator can a) use an idiom of similar meaning and form, b) use an idiom of similar meaning but dissimilar form, c) borrow the source language idiom, d) paraphrase the idiom, e) omit a play on an idiom, f) omit the entire idiom and g) compensate - which would entail omitting the idiom where it appears in the ST, and translating another expression that is not an idiom in the ST, with an idiom in the TT. There is, of course, another option that would be based on the analysis of the function of the idiom in the ST, as well as on the fact that the target reader does not know what the individual words which constitute the idiom mean and how they differ from the combined meaning of the idiom.

Bryson's account of the development of GAE includes numerous examples of the use of common idioms, their origin and meaning. In his writing, they are relevant for both their literal and idiomatic meaning. Consequently, omitting one of them leaves the target reader with only half the information s/he needs in order to follow Bryson's description. Examples are numerous, but we take here an excerpt describing money-related idioms:

\begin{abstract}
Many slang terms and other like expressions associated with money date from the nineteenth century. Americans have been describing money as beans (as in 'I haven't got a bean') since 1810 and as dough since at least 1851, when it was first recorded in the Yale Tomahawk. Small change has been around since 1819, not worth a cent since the early 1820s, and not worth a red cent since 1839. (Bryson 1994/1998, p. 84)

Mnogi termini u slengu i slični izrazi povezani s novcem potiču iz devetnaestog veka. Amerikanci su opisivali novac kao pasulj (kao u 'nemam ni zrno pasulja') od 1810. i kao testo najmanje od 1851. kad je to prvi put zabeleženo u Jejlskom tomahavku. Sića se koristi od 1819, ne vredi ni centa od početka dvadesetih godina devetnaestog veka, a ne vredi ni pišljivog centa od 1839. (Brajson 2010, p. 111)
\end{abstract}

Three procedures are identifiable in the translation of this segment, and their choice seems to be influenced by the availability of the corresponding idiom in the target language:

a) translation of the meaning of the words that make up the idiom (beans-pasulj, dough - testo) combined with a literal translation of the idiom (I haven't got a bean nemam ni zrno pasulja),

b) translation of the meaning (Small change - sića) and

c) translation by an idiomatic expression in the target language (not worth a red centne vredi ni pišljivog centa). 
The strategy wavers in the last example. In the idiom Not worth a red cent, 'red' could have been translated literally instead of idiomatically, because the individual literal meanings of the words reveal the imagery behind the expression, that the cent is red and not insignificant, as it is in the Serbian expression. The next couple of sentences show that the translator has intuitively reached the same conclusion in another section of the text:

Upper crust dates from 1832, easy money from 1836, C-note (short for century note) for $\$ 100$ bill from 1839, flat broke and dead broke from the 1840s. Americans have been referring to a dollar as a buck since 1856 (it comes from buckskin, an early unit of exchange). (Bryson 1994/1998, p. 84)

Gornja korica (upper crust) datira od 1832, lake pare (easy money) od 1836, s-novčanica (c-note, skraćeno od senčeri novčanice) za banknote od 100 dolara od 1839, sasvim švorc (flat broke) $i$ dibidus švorc (dead broke) od četrdesetih godina devetnaestog veka. Amerikanci dolar pominju kao bak (buck) od 1856. (reč potiče od reči za jelensku kožubuckskin, koja se u početku koristila kao sredstvo razmene). (Brajson 2010, p. 111)

The translation is interspersed with such segments, where the reader can actually see all the elements of the information needed to understand the specific areas in which GAE developed. But then, in the next example, this strategy is abandoned:

The following is no more than a bare sampling: [...] to whitewash (1808); having an axe to grind (1811); keep a stiff upper lip (yes, it's an Americanism, 1815); no two ways about it (1818); fly off the handle (1825); to move like greased lightning (1826); to have a knock down and dragout fight (1827); ... (Bryson 1994/1998, p. 84)

Slede samo neki primeri: [...] to whitewash (krečiti) (1808); having an axe to grind (imati sebičan motiv) (1811); keep a stiff upper lip (da, to jeste amerikanizam, 1815); ** no two ways about it (nema drugog izbora) (1818); fly off the handle (izgubiti živce) (1825); [/]; to have a knockdown and dragout fight (izuzetno nasilna tuča) (1827); ...

** praviti se mrtav-hladan (Prim.prev.)

(Brajson 2010, p. 112)

There are no binary errors here; all the translations are correct at the phrase level, with various procedures applied, depending on the availability of an idiom with the same meaning in Serbian. The problem is that the information the reader receives is never complete - the reader either gets one or the other:

- semantic interpretation, no imagery preserved (having an axe to grind - imati sebičan motiv/have a selfish motive; no two ways about it - nema drugog izbora/there is no other choice; to have a knockdown and dragout fight - izuzetno nasilna tuča/extremely violent fight)

- idiomatic translation, no imagery preserved (keep a stiff upper lip - **praviti se mrtav hladan/pretend to be dead cold about something; fly off the handle - izgubiti živce/lose control over one's feelings)

- literal translation, imagery preserved, lost meaning (to whitewash-krečiti).

This change of strategy indicates that the translator has solved problems on a case by case basis, and is motivated by the ST alone. This is one of the 29 sections printed with grey background in the book in Serbian. These sections are from one paragraph to three pages long and this change in the colour of the page (all of the others are white) is not explained anywhere in the book. The book contains 515 pages in all, so the 29 grey pages are very noticeable. Within the functionalist perspective, these sections could be either 
omitted or accompanied with additional information in order to make them appropriate to the target reader. If they are to be preserved, then the target reader's perspective would require a "thick" translation (Appiah 1993) of these sections, which preserves the elements of culture as well, by literal translation of the imagery coupled with a translation of the idiom's meaning.

\subsection{What exactly changed in pronunciation?}

The sections of the text about AE pronunciation are also grey, and they too are meaningless for those who do not speak English. As the back translation (BT) of the following example shows, the TT follows the ST syntactically, lexically and stylistically, without breaking any of the norms of the Serbian language:

There was no sound equivalent to the ah in the modern father and calm. Father would have rhymed with the present-day gather and calm with ram. (Bryson 1994/1998, p. 18)

Nije postojao glas ekvivalentan sa ah $u$ savremenim rečima father $i$ calm. Father bi se rimovalo sa današnjim gather $a$ calm sa ram. (Brajson 2010, p. 38)

There was no sound equivalent to the ah in the contemporary words father and calm. Father would have rhymed with the present-day gather and calm with $\mathrm{ram}$.(BT)

The problem here is as elsewhere - it cannot be presupposed that the Serbian reader knows that $a h$ is not pronounced as $A H$, but as a long $a$, nor that the $a$ in father is pronounced differently from the $a$ in gather. The segment would only become meaningful with some significant additions to the ST: phonetic transcriptions of the words used as examples, as well as a list of pronunciation symbols and their explanations, akin to the ones found in dictionaries of English.

\subsection{When is literal not literal enough?}

A functionalist approach to translation encompasses a range of procedures, from word-for-word translations, to paraphrases, additions and omissions. Their application depends on the purpose at the level of communicative situation as well as at the level of individual words and phrases. The purpose can sometimes go against a goal of achieving a fluent, elegant translation. We can observe this in the following example:

Often they [the first colonists] took the simplest route and gave the new creatures names imitative of the sounds they made - bobwhite, whippoorwill, katydid - and when that proved impractical they fell back on the useful, and eventually distinctively American, expedient of forming a new compound from two older words.

Colonial American English positively teems with such constructions: jointworm, glowworm, eggplant, canvasback, copperhead [...] These new terms had the virtues of directness and instant comprehensibility - useful qualities in a land whose populace included increasingly large numbers of non-native speakers - which their British counterparts often lacked. Frostbite is clearly more descriptive than chilblains, sidewalk than pavement, eggplant than aubergine, doghouse than kennel, bedspread than counterpane, whatever the English might say. (Bryson 1994/1998, p. 26)

Često su birali najjednostavnije rešenje i novim stvorenjima davali imena koja su oponašala bobwhite (mala američka prepelica), whippoorwill (američki leganj), katydid (zeleni 
skakavac) - a kada se ispostavilo da je to nepraktično, vratili su se korisnom, te na kraju osobeno američkom, sredstvu formiranja novih kovanica od dve starije reči.

Kolonijalni američki engleski bezmalo kipi od takvih konstrukcija: jointworm (larva), glowworm (svitac), eggplant (plavi patlidžan), canvasback (severnoamerička divlja patka), copperhead (zmija otrovnica) [...] Frostbite je nedvosmisleno deskriptivnije od chilblains, sidewalk od pavement, eggplant od aubergine, doghouse (štenara) od kennel, bedspread (posteljina) od counterpane, šta god Englezi govorili. (Brajson 2010, p. 47)

The translation closely follows the ST, with the addition of Serbian equivalents for most of the concepts listed here. Importantly, the translation does not offer the individual meaning of the constituent words in the GAE compounds, just their combined meanings. In this sense, jointworm is followed by the Serbian name of this creature (larva). Considering the purpose of this segment, the essential information is the meaning of the constituents and their relation to the meaning of the compound they create.

It would therefore be more meaningful if each word in English were followed by the translations of each of the constituents too, e.g. jointworm (spojeni+crv=larva). Considering the number of examples and the level of detail the author provides (this is a book for specialists or serious language lovers) such additions would not be cumbersome or superfluous. On the contrary, they are especially missed in the last sentence where the target reader, not knowing the meaning of the words side, walk and pavement, cannot make any sense of it.

\subsection{How (in)visible can a translator be?}

One corollary of the expectation of achieving the equivalent effect for the TT reader is the invisibility of the translator. Be it prose or poetry, fiction or nonfiction, a translation is judged acceptable by most publishers, reviewers, and readers if the text is fluent and the absence of any linguistic or stylistic peculiarities makes it seem transparent, giving the appearance that the translation is not a translation but the 'original' (Venuti 1995:1). This is why translators' notes, which can be viewed as a sign of insufficient skill and be cumbersome to read, drawing the reader's attention to the translator, are deemed to be undesirable.

Paradoxically, the translator's absence is highly visible in the translation of Bryson's book about English. And, this has consequences for the reader, as we shall shortly see. A book about English cannot do without English:

A bare sampling of words that entered English around the time of the Pilgrims gives some hint (another Shakespeare coinage, incidentally) of the lexical vitality of the age: alternative (1590); incapable (1591); noose (1600); nomination (1601); fairy, surrogate and sophisticated (1603); option (1604); creak, in the sense of a noise, and susceptible (1605); coarse, in the sense of being rough (as opposed to natural), and castigate (1607); obscenity (1608); tact (1609); commitment, slope, recrimination and gothic (1611); coalition (1612); freeze, in a metaphoric sense (1613); nonsense (1614); cult, boulder and crazy, in the sense of insanity (1617); customer (1621); inexperienced (1626).(Bryson 1994/1998, p. 23)

Puko uzorkovanje reči koje su ušle u engleski otprilike u vreme Hodočasnika ukazuje nam (uzgred, to je još jedna Šekspirova izmišljotina)* na leksičku vitalnost tog doba: alternative (1590); incapable (1591); noose (1600); nomination (1601); fairy, surrogate $i$ sophisticated (1603); option (1604); creak, u smislu zvuka, and susceptible (1605); coarse u smislu da je nešto grubo (nasuprot prirodnom), $i$ castigate (1607); obscenity (1608); tact (1609); 
commitment, slope, recrimination $i$ gothic (1611); coalition (1612); freeze, $u$ metaforičkom smislu (1613); nonsense (1614); cult, boulder $i$ crazy, u smislu ludila (1617); customer (1621); inexperienced (1626).

* 'ukazuje' - u originalu: gives some hint (Prim. prev.) (Brajson 2010, p. 43)

A bare sampling of words that entered English around the time of the Pilgrims indicates (by the way, this is another of Shakespeare's inventions) the lexical vitality of the age: [...]

* 'indicate' - in the original: gives some hint (Translator's note).(BT)

An English speaker can draw many conclusions about the English words listed in this section: whether they are common or rare, which lexical field they belong to, the level of formality and other nuances, thus grasping how important they are for GAE today. The target reader cannot be presumed to speak English, so from a functionalist perspective a significantly longer TT would be needed, one which would include the translations of all of these words, in the main text or in a footnote.

In the majority of cases, however, even when the footnote is used for additional information, as is the case with the explanation of 'indicate' in the above example, the meaning is expressed in too few words for the reader to really understand it. Using the phrase gives some hint, the author transfers a double meaning - the first is indicate, and the other is the information that it was Shakespeare who coined the phrase. The translation tries to render this double meaning in the footnote, but unsuccessfully, mostly because it follows the syntactic structure of the source sentence. The footnote offers the limited information that indicate was written as gives some hint in the ST; again, the reader does not get the information about the relationship between the meaning of the verb ukazuje and the English expression. A translation that takes into account the differences between the ST and the TT reader would have a slightly paraphrased sentence that renders the double information explicit:

Puko uzorkovanje reči koje su ušle u engleski otprilike u isto vreme kad i hodočasnici, daje nam nagoveštaj leksičke vitalnosti tog doba: (...) Inače, i izraz give a hint (dati nagoveštaj) smislio je Šekspir.

A simple sampling of the words that entered English approximately at the same time as the Pilgrims, give us a hint of the lexical vitality of this age [...] Otherwise, the expression give a hint (dati nagoveštaj) was also coined by Shakespeare. (BT)

\section{CONCLUDING REMARKS}

We could go on listing the examples which lead to the same conclusion: the yardstick in this translation was only the ST. It does not take into account that the ST reader and TT reader speak different languages, and that this is one of the most relevant factors in this book because the subject matter is English.

All the examples analysed here would fall into the pragmatic category. As Nord (1991/2005:57) notes, the importance of considering the addressee's situation has been present even in the writings of theorists (Wills, Koller, and Neubert, among others) working within the equivalence paradigm, but "there is no other factor which is neglected so frequently in translation practice". It seems that when the ST looms large, the reader is rendered small. For functionalists, the problem lies in the understanding of the defining features of translation: is it the relationship between the source and the target, or the 
reason why a certain text needs to be translated, its purpose in the target culture? Our analysis has hopefully shown that a predominant consideration for the ST-TT relationship can render certain segments of the ST 'untranslatable' and the translation meaningless. Equivalence to the ST is not a useless concept, but it is a concept of limited use. It is applicable in situations when the search for any type of equivalence can lead to a meaningful translation for the target reader. One important consequence of the functionalist approach is that it allows translators to affirm that segment of their competence that sets them apart from bilinguals or (neural) machine translation - the ability to decide whether equivalence to the ST should be the overriding principle.

\section{REFERENCES}

Appiah, K. A., (1993), Thick Translation, Callaloo 4, Vol. 16: pp. 808-819.

Baker, M., (2011),In Other Words, Routledge, London and New York.

Bryson, B., (1994/1998), Made in America, Transworld Publishers, London.

Brajson, B., (2010), Made in America, (transl. Goran Skrobonja), Laguna, Beograd.

Catford, J. C., (1965), A Linguistic Theory of Translation, OUP, London.

Chesterman, A., Wagner, E., (2002), Can Theory Help Translators? A Dialogue Between the Ivory Tower and the Wordface, St. Jerome Publishing, Manchester.

Colina, S., (2011), "Evaluation/Assessment”, In: Gambier, Y. and Van Doorslaer, L. (eds.) Handbook of Translation Studies, Vol. 2, John Benjamins Publishing Company, Amsterdam/Philadelphia, pp. 43-48.

Eraković, B., (2002), O prevođenju urbanog američkog supstandarda, Pokrajinskisekretarijat za nauku i kulturu, Novi Sad.

Eraković, B., (2010), "Prevođenje knjiga za decu, funkcionalni pristup”, In: Subotić, Lj. and Živančevć-Sekeruš, I. (eds.), Susret kultura, Filozofski fakultet, Novi Sad, pp. 839-846.

Eraković. B., (2013), „Prevođenje knjiga za decu: problem strategije“, In: Živančević-Sekeruš, I. (ed.), Susret kultura, Filozofski fakultet, Novi Sad, pp. 789-799.

Eraković, B., (2018), „Elementi akulturacije u prevođenju vesti iz sveta sa engleskog na srpski“, Nasleđe 39, pp.117-132.

Fawcett, P., (1997), Translation and Language: Linguistic Theories Explained, St Jerome Publishing, Manchester.

Holmes, J. S., (2000), "The Name and Nature of Translation Studies", In: Venuti, L. (ed),The Translation Studies Reader, Routledge, London and New York, pp. 172-185.

Kenny, D., (2009), "Equivalence”, In: Baker, M. and Saldanha, G. (eds.) Encyclopedia of Translation Studies. Routledge, London and New York, pp. 96-99.

Leal, A., (2012), "Equivalence", In: Gambier, Y. and Van Doorslaer, L. (eds.) Handbook of Translation Studies, Vol. 3, John Benjamins Publishing Company, Amsterdam and Philadelphia, pp. 39-46.

Munday, J., (2008), Introducing Translation Studies: Theories and Applications, Routledge, London and New York.

Nida, E. A.,(1964), Toward a Science of Translating, E.J. Brill, Leiden.

Nida, E. A., Taber, C. R. (1969), The Theory and Practice of Translation, E. J. Brill, Leiden.

Newmark, P., (1988), A Textbook of Translation, Prentice-Hall International, Hemel Hempstead.

Nord, C., (2005), Text Analysis in Translation, Rodopi, Amsterdam and New York.

Nord, C., (2013), "Functionalism in Translation Studies", In: Millan, C., Bartring, F, (eds.), The Routledge Handbook of Translation Studies, Routledge, London and New York, pp. 201-212.

Pym, A., (1992), “Translation Error Analysis and the Interface with Language Teaching”, In: Dollerup, C. and Loddegaard, A., (eds.) The Teaching of Translation, John Benjamins, Amsterdam, pp. 279-288.

Pym, A., (1995), “European Translation Studies, Une science qui derange, and Why Equivalence needn't be a Dirty Word”. Traduction, Terminologie, Réaction1, Vol 8: pp. 153-176.

Snell-Hornby, M., (1988), Translation Studies: An Integrated Approach, John Benjamins, Amsterdam and Philadelphia.

Snell-Hornby, M., (2006), The Turns of Translation Studies: New Paradigms or Shifting Viewpoints?, John Benjamins, Amsterdam and Philadelphia.

Venuti, L., (1995), The Translator's Invisibility: A History of Translation. Routledge, London/New York. 


\section{MADE IN AMERICA BILA BRAJSONA U PREVODU NA SRPSKI: EKVIVALENCIJA S IZVORNIM TEKSTOM KAO KLJUČNI KRITERIJUM U PREVOĐENJU}

U radu pokazujemo uticaj koji implicitno shvatanje prevođenja kao uspostavljanja ekvivalencije sa izvornim tekstom ima na prevodiočeve odluke. Analiziran je srpski prevod knjige o istoriji američkog engleskog Made in America, viđene očima Bila Brajsona, pisca koji je svoju slavu stekao duhovitom putopisnom prozom. Analizirani prevod ne sadrži takozvane 'binarne greške’ koje bi ukazivale na nekompetentnog prevodioca, ali obiluje primerima neostvarene unutartekstualne koherentnosti sa stanovišta ciljnog čitaoca. Razlozi za nekoherentnost nalaze se u implicitnom shvatanju prevođenja pre svega kao traganja za ekvivalencijom u odnosu na izvorni tekst, što za posledicu ima zanemarivanje cilja prevođenja i karakteristika čitaoca prevoda. U radu kontrastiramo primere iz objavljenog prevoda sa primerima primene funkcionalističkog pristupa u istim segmentima i razmatramo njegov uticaj na vidljivost prevodioca.

Ključne reči: funkcionalistički pristup, ekvivalencija, unutartekstualna koherentnost, međutekstualna koherentnost 